\title{
THE FUTURE OF INDONESIA AND GLOBAL AGRICULTURE: RICE CONSUMPTION AND AGRICULTURAL MODERNIZATION
}

Ade Marsinta Arsani
Statistics Indonesia, Padjadjaran University
ademarsinta@gmail.com

Diterima: Desember 2019; Disetujui: April 2020

\begin{abstract}
In the industry revolution 4.0 era, the agriculture sector still has an important position in human life because, without this sector, human capital development cannot be well developed. Globally, the share of agriculture, forestry, and fishing sector has declined significantly in the last two decades. However, the demand on agriculture product, especially rice, incline every year. Rice supply and demand projection with appropriate methods are very important because their result affect how agricultural policies are applied. The aim of this study is to examine the likely evolution of rice consumption in Indonesia and forecast the Indonesia rice consumption per capita based on global data. The results indicate the income elasticity of demand for rice in the Indonesia has become negative. The forecast of model show that Indonesia's rice demand will keep incline, at least in the next five years. Due to those result, in order to maintain farmers' wealth, modernization in agriculture is needed. Government has encouraged some programs such as Simluhtan, Katam, Si Mantap, Smart Farming, Smart Green House, Autonomous Tractor, dan Smart Irrigation to accelerate the agricultural transformation. Unfortunately, human resource quality becomes a problem. Indonesia need massive effort so that modernization in agriculture works well.
\end{abstract}

Keyword: agriculture, forecasting, inferior, modernization

Abstraksi. Sektor pertanian masih memiliki posisi penting dalam kehidupan manusia di era revolusi industri 4.0. Tanpa sektor ini, pengembangan modal manusia tidak dapat dikembangkan dengan baik. Secara global, pangsa sektor pertanian, kehutanan, dan perikanan telah menurun secara signifikan dalam dua dekade terakhir. Namun, permintaan produk pertanian, terutama beras, cenderung meningkat setiap tahun. Proyeksi penawaran dan permintaan beras dengan metode yang tepat sangat penting karena hasilnya mempengaruhi bagaimana kebijakan pertanian diterapkan. Tujuan dari penelitian ini adalah untuk menguji kemungkinan evolusi konsumsi beras di Indonesia dan memperkirakan konsumsi beras Indonesia per kapita berdasarkan data global. Hasilnya menunjukkan elastisitas pendapatan dari permintaan beras di Indonesia telah menjadi negatif. Pemodelan menunjukkan bahwa permintaan beras Indonesia akan terus meningkat, setidaknya dalam lima tahun ke depan. Karena hasil tersebut, untuk menjaga kekayaan petani, diperlukan modernisasi di bidang pertanian. Pemerintah telah mendorong beberapa program seperti Simluhtan, Katam, Si Mantap, Pertanian Cerdas, Rumah Kaca Cerdas, Traktor Otonom, dan Irigasi Cerdas untuk mempercepat transformasi pertanian. Sayangnya, kualitas sumber daya manusia menjadi masalah. Indonesia membutuhkan upaya besar-besaran agar modernisasi dalam pertanian berjalan dengan baik.

Kata kunci: inferior, modernisasi, estimasi, pertanian 


\section{INTRODUCTION}

Although there is a long historical literature examining the topic, the role of agriculture in economic development is complicated enough. Timmer (1988) said that the structural transformation itself, which is a general equilibrium process not easily understood from within the agricultural sector. Another reason for controversy over the role of agriculture stems from the heterogenity of agricultural endowments and the vastly different cropping systems seen in Latin America, Africa and Asia (Bravo-Ortega \& Lederman, 2005).

In this industry revolution $4.0 \mathrm{era}$, the agriculture sector still has an important position in human life because, without this sector, human capital development cannot be well developed. Due to the economic transformation, the share of the agriculture sector in GDP in many countries has declined every decade. Globally, the share of agriculture, forestry, and fishing sector has declined significantly in the last two decades, from 7.60 percent in 1995 to only 3.42 percent in 2017. While in Indonesia, this figure has slightly fallen from 17.42 percent in 1995 to 12.81 percent in 2018. Not only declining in share, but the percentages of employment also decline. Based on ILO data, both in general and in Indonesia, the employment in agriculture decreased significantly from 43.80 per cent and 54.02 per cent in 1991 to only 28.41 percent and 30.79 percent in 2017, respectively. The government should pay attention to this phenomenon, because the agriculture sector, especially the paddy rice sector, has an important role in Indonesia's economy.

Like most countries in Asia, Indonesia is one country that makes rice as the main source of carbohydrates. Based on World
Bank data (2010), Indonesia is the thirdlargest rice consuming country in the world after China and India, which is around 28 million metric tons annually. This figure is expected to rise every year along with an increase in population. Unfortunately, the increase in rice demand was not followed by an increase in rice production. The existence of global climate change has a big influence on the decline in rice production worldwide (The International Rice Research Institute, 2000). This may give rise to the need for new production approach to meet the competing demands for rice. Although there are not too much changes in global rice demand from year to year (only 0.27 percent based on Sirikanchanarak et al., 2017), rice demand supply and demand projection are needed to ensure the food security (Gao et al., 2014). Sufficiency of food affects the nutrients in which support the creation of quality human resources as the motor the national development (Ohyver \& Pudjihastuti, 2018). Furthermore, the rice demand projections will help many institutions, such as: governments, businesses, and international organizations to allocate investment resources for raising rice production and ensure that global rice supplies are enough and are produced in the most efficient way (Timmer C. B., 2010).

Rice supply and demand projection with appropriate methods are very important because their result affect how agricultural policies are applied. Several studies show that the key determinants of future rice consumption was the rate of population growth, income growth, declining real price for rice, and the gradual shift of workers from rural to urban employment (The International Rice Research Institute, 2000; Kubo \& Purevdorj, 2004; Timmer C. B., 2010). Although rice demand is projected to 
incline every year, some studies show that income elasticities of rice demand have declined in recent years in many of these countries and, in several, have become negative ( Ito et al., 1989; Peterson et al., 1991).

The forecasting of rice consumption and its determinants is crucial. Therefore, the aim of this study are to examine the likely evolution of rice consumption in Indonesia and forecast the Indonesia rice consumption per capita based on global data. We separate countries into 7 groups based on regions: East Asia\&Pacific, Europe and Central Asia, Latin America and Carribbean, Middle East and North Africa, North America, South Asia, and Sub Saharan Africa. This classification not only based on their region, but also based on their rice consumption behavior.

\section{DATA AND METHODOLOGY}

This research uses data from several sources: rice consumption data from Food and Agricultural Organization; GDP and income data from World Bank; and, price data from IMF. The models in this study are based on models in Peterson et al. (1991) and Sirikanchanarak et al. (2017) with several modification due to the availability and compability of the data.

Peterson et al. (1991) developed their model to account various influences on rice disappearance. They argued that human rice consumption should be estimated on a per capita basis to allow an assessment of the potentially conflicting effects of population and income growth. They adopted loginverse-log model used by Ito et al. (1989). Then, we modify their model to make it compatible with Indonesia's consumption pattern, i.e use chicken rather than pork price. Our model specification is:

$$
\log R C=\beta_{0}+\beta_{1} \frac{1}{P C Y}+\beta_{2} \log P C Y+\beta_{3} \log C M+\beta_{4} \log R W R+\varepsilon \ldots \ldots \ldots \ldots \ldots . . . . . .1 .1
$$

Where $\mathrm{RC}$ is per capita rice consumption $(\mathrm{kg}), \quad \mathrm{PCY}$ is real per capita income (rupiah), $\mathrm{CM}$ is real price of chicken (rupiah), and RWR is ratio of world rice to world wheat prices. This model use Indonesia's data in 2007-2018 with semiannual period.
Meanwhile, to forecast rice consumption, we adopt model from Sirikanchanarak,et.al (2017) in which using dynamic fixed effect panel regression with GMM estimators. The model specification is:

$$
P R C_{i t}=\alpha_{0}+\alpha_{1} P R C_{i(t-1)}+\alpha_{2} G D P_{i t}+\alpha_{3} R P_{i t}+\varepsilon_{i t} \ldots \ldots \ldots \ldots \ldots \ldots \ldots \ldots \ldots \ldots \ldots \ldots \ldots \ldots \ldots \ldots \ldots \ldots \ldots \ldots \ldots \ldots \ldots . . .2
$$

Where PRCit is per capita rice global data from 1980 to 2013 with some consumption of country $i$ at time t, GDPit is missing information in several countries. gross domestic product per capita of country $i$ at time $t$, and RPit is world rice price at time $t$. The actual data used for model selection and estimation are annual 


\section{RESULT AND DISCUSSION}

To examine the evolution of rice consumption in Indonesia, the modified model from Peterson et al. (1991) is used.
As a moslem country, in which has low rate of pork consumption, instead using pork as rice's complement, this study use chicken consumption. The result is as below:

Table 1.

Rice Consumption Model

\begin{tabular}{lcc}
\hline & $(1)$ & $(2)$ \\
VARIABLES & $\log$ RC & $\log$ RC \\
\hline PCY_1 & $-2.629 \mathrm{e}+07 * *$ & $-2.454 \mathrm{e}+07 *$ \\
& $(1.225 \mathrm{e}+07)$ & $(1.192 \mathrm{e}+07)$ \\
log_PCY & $-1.169 * *$ & $-1.150^{* * *}$ \\
& $(0.410)$ & $(0.376)$ \\
log_CM & 0.000986 & \\
& $(0.0322)$ & 0.0139 \\
log_RWR & 0.0131 & $(0.0134)$ \\
& $(0.0135)$ & 0.0171 \\
log_BM & & $(0.0263)$ \\
& & $22.42^{* * *}$ \\
Constant & $22.97 * * *$ & $(6.896)$ \\
& $(7.348)$ & 24 \\
Observations & 24 & 0.914 \\
R-squared & 0.912 & \\
\hline \multicolumn{3}{c}{ Standard errors in parentheses } \\
& $* * * \mathrm{p}<0.01, * * \mathrm{p}<0.05, * \mathrm{p}<0.1$
\end{tabular}

The result reported in the table show that there is a strong correlation between income and consumption. Both income coefficients are significant and of the expected sign. Those coefficient signs indicate the income elasticity of demand for rice in the Indonesia has become negative, it is likely that per capita rice consumption will decline in the future as incomes continue to grow. This result is similar with condition in several Asian country, such as China and Japan ( (Peterson et al.,1991; Ito et al., 1989; Chern et al., 2003). This result also show that there is an evolution in the pattern of rice consumption in Indonesia. FAO's research in 1971 found that the income elasticities in rice demand in Indonesia at that time still positive at about 0.70 (FAO, 1971). Study conducted
Sumarwan (2010) also found that rice consumption on average per capita per week has decreased during 1999-2009. However, although there is an indication that rice in Indonesia becomes an inferior goods, but the model does not show a significant cross-price demand elasticity between rice and chicken or beef. This result does not support the argument that high quality food products such as meat are being substituted for rice. The coefficient of ratio of wheat and rice's also not significant. This result is not surprising as wheat and its differentiated products are not the staple food for most of Indonesian people. Also, the trade of wheat products (especially wheat flour) are controlled by the government. 
Even though there is an indication that rice becomes an inferior goods, due to the high demand of rice in Indonesia, the forecasting of rice consumption are still essential for public policy. Using model from Sirikanchanarak, Tungtrakul, \& Sriboonchitta (2017), the estimated equation is as below:

Table 2.

Per capita Rice Consumption Model

\begin{tabular}{|c|c|c|c|c|c|c|c|c|}
\hline VARIABLES & $\begin{array}{c}\text { East Asia } \\
\& \text { Pacific } \\
\text { prc }\end{array}$ & $\begin{array}{c}\text { Europe \& } \\
\text { Central } \\
\text { Asia } \\
\text { prc }\end{array}$ & $\begin{array}{c}\text { Latin } \\
\text { America } \\
\& \\
\text { Caribbean } \\
\text { prc }\end{array}$ & $\begin{array}{l}\text { Middle } \\
\text { East \& } \\
\text { North } \\
\text { Africa } \\
\text { prc }\end{array}$ & $\begin{array}{c}\text { North } \\
\text { America } \\
\text { prc }\end{array}$ & $\begin{array}{c}\text { South } \\
\text { Asia } \\
\text { prc }\end{array}$ & $\begin{array}{c}\text { Sub- } \\
\text { Saharan } \\
\text { Africa } \\
\text { prc }\end{array}$ & All \\
\hline L.prc & $\begin{array}{c}0.644 * * * \\
(0.0317)\end{array}$ & $\begin{array}{c}0.625 * * * \\
(0.0233)\end{array}$ & $\begin{array}{c}0.642 * * * \\
(0.0272)\end{array}$ & $\begin{array}{c}0.831 * * * \\
(0.0258)\end{array}$ & $\begin{array}{c}0.851 * * * \\
(0.0681)\end{array}$ & $\begin{array}{c}0.877 * * * \\
(0.0367)\end{array}$ & $\begin{array}{c}0.828 * * * \\
(0.0190)\end{array}$ & $\begin{array}{c}0.726 * * * \\
(0.0171)\end{array}$ \\
\hline gdpgrowth & $\begin{array}{c}0.000875 \\
(0.0360)\end{array}$ & $\begin{array}{c}0.0484 * * \\
(0.0199)\end{array}$ & $\begin{array}{l}-0.0393 \\
(0.0254)\end{array}$ & $\begin{array}{l}0.0320 * \\
(0.0191)\end{array}$ & $\begin{array}{l}-0.0289 \\
(0.0388)\end{array}$ & $\begin{array}{c}0.0382 \\
(0.0492)\end{array}$ & $\begin{array}{l}-0.0255 \\
(0.0195)\end{array}$ & $\begin{array}{r}-0.00222 \\
(0.0111)\end{array}$ \\
\hline riceprice & $\begin{array}{l}0.000727 \\
(0.00106)\end{array}$ & $\begin{array}{l}0.00161 * * \\
(0.000742)\end{array}$ & $\begin{array}{c}0.00124 \\
(0.000773)\end{array}$ & $\begin{array}{l}0.000421 \\
(0.00108)\end{array}$ & $\begin{array}{c}0.000863 \\
(0.000807)\end{array}$ & $\begin{array}{l}0.000950 \\
(0.00168)\end{array}$ & $\begin{array}{c}0.00240 * * * \\
(0.000870)\end{array}$ & $\begin{array}{c}0.00181 * * * \\
(0.000431)\end{array}$ \\
\hline Constant & $\begin{array}{c}18.96 * * * \\
(1.738)\end{array}$ & $\begin{array}{c}7.256 * * * \\
(0.531)\end{array}$ & $\begin{array}{c}7.787 * * * \\
(0.643)\end{array}$ & $\begin{array}{c}5.209 * * * \\
(0.939)\end{array}$ & $\begin{array}{l}0.764 * \\
(0.433)\end{array}$ & $\begin{array}{c}6.633 * * * \\
(1.935)\end{array}$ & $\begin{array}{c}3.988 * * * \\
(0.572)\end{array}$ & $\begin{array}{c}7.608 * * * \\
(0.519)\end{array}$ \\
\hline $\begin{array}{l}\text { Observations } \\
\text { Number of } \\
\text { countryid }\end{array}$ & $\begin{array}{c}706 \\
37\end{array}$ & $\begin{array}{c}1,125 \\
64\end{array}$ & $\begin{array}{c}1,045 \\
49\end{array}$ & $\begin{array}{c}441 \\
30\end{array}$ & $\begin{array}{c}96 \\
3\end{array}$ & $\begin{array}{c}185 \\
11\end{array}$ & $\begin{array}{c}1,202 \\
64\end{array}$ & $\begin{array}{c}4,800 \\
170\end{array}$ \\
\hline
\end{tabular}

Based on the result, although it does not statistically significant, there is a negative relationship between rice consumption per capita growth and GDP growth in general. However, when the model is estimated in different regions, the results become vary. In Europe \& Central Asia, Middle East \& North Africa, there are positive relationship between GDP growth and rice consumption per capita. It means that while in several regions rice becomes inferior goods, in those two regions, rice still becomes normal goods.

In the case of rice consumption per capita growth and rice price growth, there are significant and positive relationship in Europe \& Central Asia and Sub-Saharan Africa regions, while it is not significant for the rest of regions.

Lastly, we use the model to forecast the Indonesia rice consumption per capita in the five next years (2014-2018). We compare two models: East Asia \& Pacific model and global model. Those two models indicate that the rice consumption percapita in 20142018 remain stable although their prediction figures are quite far with the actual figures and global model predict closer than East Asia \& Pacific model.

Based on the result of this study and several previous studies, although rice in Indonesia starts to transform into inferior goods, but rice still be staple food for most of Indonesian people. Therefore, because of the limitation of rice production in Indonesia and due to the efficiency factors, Indonesia should import rice from abroad. In fact, Indonesia tried to be self-sufficient in rice production, but this increasingly costly effort has failed to eliminate the need to import. Based on his study, Dawe (2008) suggest that it is unduly costly for Indonesia to aim for self-sufficiency in rice: it will probably need to import rice indefinitely to maintain domestic prices at levels comparable to world prices. Another 
disadvantage self-efficiency policy is that domestic production fluctuations can cause considerable instability in domestic prices. Because cost becomes one of important obstructions in rice self-sufficient program, agriculture modernization is needed to make the policy more effective and efficient. Modernization in agriculture faces four main issues, namely: demographics, scarcity of natural resources, climate change, and food waste (De Clercq, Vats, \& Biel, 2018). The traditional approach of food industry (including rice production) is undergoing a fundamental transformation. The grain and cereals production rose 300 per cent over 19602004 in East Asia. This phenomenon is enabled by modern farming practices. But this development also bring side effect in climate changes. Therefore, to avoid hunger and poverty over the world, old technologies must be maximised and the new one should be generated. World Government Summit in 2018 agreed that the coming agricultural revolution, as known as agriculture 4.0, must be a green one, with science and technology in its heart. Modern farm should work with technology, including sensors, devices, machines, and other modern information technology. These situations will let farmers be more profitable, effective, efficient, safer, and more environmental friendly. In their report, De Clercq, Vats, \& Biel (2018) argued that there are three main solution to disrupt old farming practice: produce differently using new techniques; use new technologies to increase efficientcy in food chain; and, incorporate crossindustry technologies and applications.

Regarding to Indonesia situation, as rice start to transform to be inferior goods but still be staple food for most people, government should maintain the farmers' wealth through agricultural modernization. Currently, farmers terms of trade index as the proxy of farmers' wealth remain stuck at $100-103$ in the last five years. To elevate farmers' economic status, modernization is a must. Indonesia government via Ministry of Agriculture have encouraged some solution to accelerate agricultural transformation in Indonesia. The agricultural transformation process must at least pay attention to 4 components which are very important in the process of adopting modern technology. The four components include "Teknoware", "Humanware", "Organoware" and "Infoware". "Teknoware" or the technology itself starts from software and hardware. The Ministry of Agriculture has prepared many tools that support the performance of extension workers facing the industrial era 4.0 such as SIMLUHTAN (Agricultural Extension Management System), E-RDKK, and cyber extensions; "Humanware" or human beings, both as technology practitioners and humans as technology recipients; "Organoware" or its organization or agricultural institution. The Ministry of Agriculture has designed the development of an IT-based Agricultural Counseling Center; and "Infoware" or the information is how to package information that can be used and easily understood by the farmers. These $\mathrm{s}$ are not enough to boost the farmers' wealth. Government should also escalate the human resource in agriculture. Based on Sakernas 2017 data, almost 90 percent of farmers only graduated from primary education. Not only level of education, but human resources in agriculture also faces aging problems. Based on 2016 Agriculture Census, more than 75 percent of farmers are above 40 years old. These situations more or less will affect the quality of agricultural 
transformation in Indonesia. Regarding to these figures, Indonesia is not ready enough to do modernization in agriculture unless there is massive effort and maximum budget to encourage people to transform.

\section{CONCLUSION}

Agriculture modernization is important to support economic growth. Although in several regions, rice becomes an inferior goods, the demand for rice still incline every year due to the population growth. To avoid adverse effects of this phenomenon, government should pay attention to modernization in agriculture by support farmers to do massive transformation.
Government should encourage farmers to work with technology, including sensors, devices, machines, and other modern information technology in order to be more profitable, effective, efficient, safer, and more environmentally friendly. Indonesia government via Ministry of Agriculture have encouraged some programs such as Simluhtan, Katam, Si Mantap, Smart Farming, Smart Green House, Autonomous Tractor, dan Smart Irrigation to facilitate massive agricultural modernization. However, need more effort to transform Indonesian farmers to to human resources quality and aging problems.

\section{REFERENCES}

Badan Pusat Statistik. (2017). Pengeluaran untuk Konsumsi Penduduk Indonesia, Buku 1. Jakarta: Badan Pusat Statistik.

Bravo-Ortega, C., \& Lederman, D. (2005). Agriculture and National Welfare Around the World: Causality and International Heterogeneity Since 1960. World Bank Policy Research Working Paper No. 3499.

Chern, W. S., Ishibashi, K., Taniguchi, K., \& Tokoyama, Y. (2003). Analysis of the Food Consumption of Japanese Households. Rome: Food and Agriculture Organization of The United Nations.

Dawe, D. (2008). Can Indonesia trust the world rice market? Bulletin of Indonesian Economic Studies, 44 no 1, 115-132.

De Clercq, M., Vats, A., \& Biel, A. (2018). Agriculture 4.0: The Future of Farming Technology. Dubai: World Government Summit.

FAO. (1971). Agricultural Commodity Projections, 1970-1980. Rome: Food and Agriculture Organization of the United Nations.

FAO. (2014). FAOSTAT Data. Rome: FAO.

Gao, M., Luo, Q., Liu, Y., \& Mi, J. (2014). Grain consumption forecasting in China for 2030 and 2050: volume and varieties. 2014 The Third International Conference on Agro-Geoinformatics, 1-6. IEEE.

Ito, S., Peterson, E., \& Grant, W. (1989). Rice in Asia: Is it becoming an inferior good? Agricultural Economics, 32-42.

Kubo, M., \& Purevdorj, M. (2004). The future of rice production and consumption. Journal of Food Distribution Research, 128--142.Gao, M., Luo, Q., Liu, Y., \& Mi, J. (2014). Grain consumption forecasting in China for 2030 and 2050: volume and varieties. 2014 The Third International Conference on Agro-Geoinformatics, 1-6. IEEE. 
Ohyver, M., \& Pudjihastuti, H. (2018). Arima Model for Forecasting the Price of Medium Quality Rice to Anticipate Price Fluctuations. Procedia Computer Science, 135, 707711. https://doi.org/10.1016/j.procs.2018.08.215

Sumarwan, U. (2010). Perubahan Pola Konsumsi Pangan Beras, Jagung dan Terigu Konsumen Indonesia Periode 1999-2009 dan Implikasinya Bagi Pengembangan Bahan Bakar Ramah Lingkungan Berbasis Pangan. Jurnal Pangan, 19(2), 157-168.

Peterson, E. W., Jin, L., \& Ito, S. (1991). An econometric analysis of rice consumption in the People's Republic of China. Agricultural Economics,, 67-78.

Sirikanchanarak, D., Tungtrakul, T., \& Sriboonchitta, S. (2017). The Future of Global Rice Consumption: Evidence from Dynamic Panel Data Approach. In K. V., S. S, \& C. N, Predictive Econometrics and Big Data. Springer.

The International Rice Research Institute (IRRI). (2000). Bigger harvest a cleaner planet. Manila: The International Rice Research Institute (IRRI).

Timmer, C. B. (2010). Long-run dynamics of rice consumption, 1960-2050. In S. Pandey, D. R. Byerlee, D. Dawe, A. Dobermann, S. Mohanty, S. Rozelle, \& B. Hardy, Rice in the Global Economy: Strategic Research and Policy Issues for Food Security (pp. 139-174). Manila: International Rice Research Institute (IRRI).

Timmer, C. P. (1988). The Agricultural Transformation. In H. Chenery, \& T. Srinivasan, Handbook of Development Economics (pp. 275-331). Amsterdam: North-Holland.

World Bank. (2010). GLOBAL CONSUMPTION DATABASE-RICE. Retrieved from The World Bank: http://datatopics.worldbank.org/consumption/product/Rice. 